\title{
THE EFFECT OF THE USE OF VIDEO ON ENGLISH VOCABULARY MASTERY OF THE ELEMENTARY SECOND LEVEL STUDENTS AT SDN 018 SAMARINDA
}

\author{
Widi Syahtia Pane ${ }^{l}$ Godefridus Bali Geroda ${ }^{2}$ \\ 1)Program Studi Pendidikan Bahasa Inggris, Fakultas Keguruan dan Ilmu Pendidikan, \\ Universitas Widya Gama Mahakam Samarinda, Indonesia \\ Jl. KH. Wahid Hasyim No. 28 RT.007 Kota Samarinda, Provinsi Kalimantan Timur \\ 2) Program Studi Pendidikan Bahasa Inggris, Fakultas Keguruan dan Ilmu Pendidikan, \\ Universitas Widya Gama Mahakam Samarinda, Indonesia \\ *Email Penulis Korespondensi: widi.pane@gmail.com,defri@uwgm.ac.id,
}

\begin{abstract}
Vocabulary is one of language components that plays an important role in communication. Through vocabulary, students can develop the four skills in English language such as listening, reading, writing, and speaking. There are many ways in teaching vocabulary and increasing vocabulary mastery. In this study, the writer used video as a technique. In this study, the writer wants to found out that has any significant effect of the use of Video on English vocabulary mastery of the elementary second level students at SDN 018 Samarinda.The design of this study was pre-experimental design. The writer gave pre-test, treatment, and post-test to one group. The sample of this study was 30 students of the elementary second level students at SDN 018 Samarinda. In analyzing data, the writer used t-test to find out the significance difference between the result before treatment (pre-test) and after treatment (post-test).In pre-test, from 30 students, 7 students got A (excellent), 6 students got B (good), 7 students got $\mathrm{C}$ (fair), 6 students got $\mathrm{D}$ (poor), and 4 students got $\mathrm{E}$ (fail). In post-test, from 30 students, 13 students got $\mathrm{A}$ (excellent), 8 students got B (good), 8 students got $\mathrm{C}$ (fair), 1 student got D (poor), and no students got $\mathrm{E}$ (fail). The mean score of vocabulary before treatment (pre-test) was fair $(67,7)$ and the mean score of vocabulary after treatment (post-test) was good $(78,7)$. The result of the findings of the study showed t-count (6.358) is greater $(>)$ than t-table (2.045) at level of significant $(\mathrm{p})=5 \%$ and $\mathrm{df}=29$. It means the null hypothesis $(\mathrm{Ho})$ is rejected and alternative hypothesis (Ha) is accepted. It means that the use of Video give very significant effects on vocabulary to the elementary second level students of SDN 018 Samarinda
\end{abstract}

Keywords:Vocabulary, Video, English Vocabulary Mastery

\section{INTRODUCTION}

The curriculum in the Elementary school has put English for lessons to study, and English is important to children to be learnt at early ages. Teaching English for children especially in the Elementary school is different from teaching English for adult because children in the Elementary school have various characteristics in learning English. we have to be active to teach them because they are beginners in learning English. Sometimes teachers have less in techniques, high typical emotion.

English has been chosen as an international language for all people in the world. It means everybody in the world must learn English in order that they can speak English. There are many people who can not speak English because they think English is difficult to learn. 
According to Fitriadi (2005, cited in Madil, 2011:1), some characteristics of young learners must be happy because they are beginners to learn English. Mostly, the children especially for the students of elementary school are interested in learning English with the funny pictures and full of color.

According to Arthur (2002, cited in Wardani, 2003:3), says that : "video can give students realistic model to imitate for the role play: can increase the awareness of other culture by teaching appropriateness and suitability; can wider the classroom repertoire and range the activities; can help utilize the latest technology to facilitate language learning; can teach direct observation of the paralinguistic feature found in association with the target language; can be offer a visual reinforcement of the target language and can lower anxiety when practicing the skill of listening".

Based on the explanation above the writer would like to investigate the effect of using video on vocabulary mastery of the elementary second level students at SDN 018 Samarinda Samarinda. In this study the writer uses Video because this media is familiar with the students and it can represent the vocabulary that students have learned.

\section{METHODOLOGY}

The design of the study was pre-experimental design. The aim of the study was to see whether using video can give better understanding in teaching English vocabulary. Based on John (1959, cited in Wilda 2009:24)," this design provides some improvement over the first, for the effects of the treatment were judged by the difference between the pretest and posttest scores". Based on that statement the writer uses pretest and posttest to one group, the writer conducts research as follow :Table 2The Research Procedure of Research Design to Conduct the Data

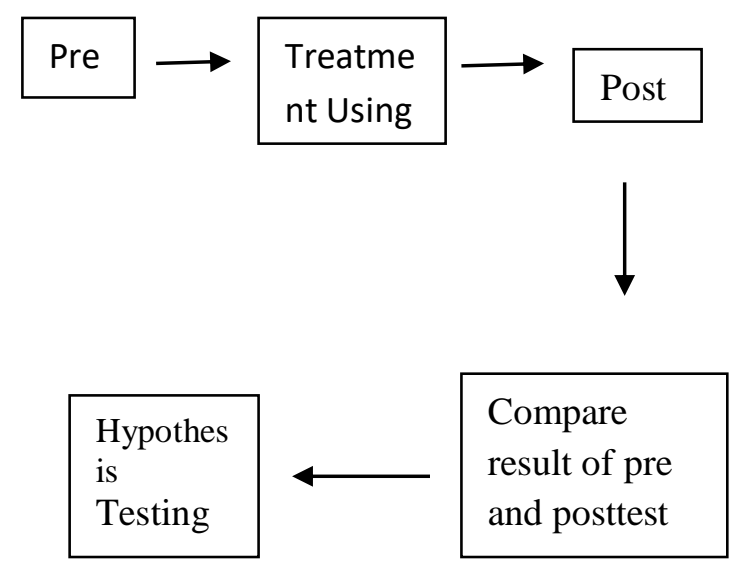

After getting the sample, the writer gave treatments to the children by using a Video. Before giving the treatment, the samples were given a pretest to know the result and to compare with posttest that being held after the treatment. After getting the posttest result, the writer found out the differences between both results, pretest and posttest.

The population of this study was the elementary second level students of SDN 018 Samarinda. The total numbers of the students are 30 from 2 classes. In taking sample, the writer follows Gay, et al (2006, cited in Ranggi, 2010:36), statement said "for experimental studies, a minimum of 30 subject per group is generally recommended".

From that statement the writer taking the sample were 30 students of SDN 018 Samarinda. All the total number of sample got treatment by using video. 
BORJU: Borneo Educational Journal

https://jurnal.fkip-uwgm.ac.id/index.php/Borju/index

E-ISSN: 2655-9323

Februari 2019, Vol. 1 No. 1

\section{FINDINGS AND DISCUSSION}

\section{The Result of Pre Test}

The following table, shows the scores of vocabulary test before teaching using video to the elementary second level students of SDN 018 Samarinda.

Table 5. The Scores of Pre-Test

\begin{tabular}{c|c|c}
\hline Number of Students & Score & Qualification \\
\hline 5 & 86.7 & $\mathrm{~A}$ \\
6 & 84.9 & $\mathrm{~A}$ \\
7 & 83 & $\mathrm{~A}$ \\
8 & 79.2 & $\mathrm{~B}$ \\
9 & 77.3 & $\mathrm{~B}$ \\
10 & 75.4 & $\mathrm{~B}$ \\
11 & 73.5 & $\mathrm{~B}$ \\
12 & 71.6 & $\mathrm{~B}$ \\
13 & 71.6 & $\mathrm{~B}$ \\
14 & 69.8 & $\mathrm{C}$ \\
15 & 69.8 & $\mathrm{C}$ \\
16 & 66 & $\mathrm{C}$ \\
17 & 66 & $\mathrm{C}$ \\
18 & 62.2 & $\mathrm{C}$ \\
19 & 60.3 & $\mathrm{C}$ \\
20 & 60.3 & $\mathrm{C}$ \\
21 & 58.4 & $\mathrm{D}$ \\
22 & 58.4 & $\mathrm{D}$ \\
23 & 56.6 & $\mathrm{D}$ \\
24 & 56.6 & $\mathrm{D}$ \\
25 & 54.7 & $\mathrm{D}$ \\
26 & 52.8 & $\mathrm{D}$ \\
27 & 49 & $\mathrm{E}$ \\
28 & 47.1 & $\mathrm{E}$ \\
29 & 45.2 & $\mathrm{E}$ \\
30 & 24.5 & $\mathrm{E}$ \\
\hline SUM & 2032.4 & \\
\hline
\end{tabular}

From the table above, we can see that sum of the score of pre test was 2032.4 and the number of the students was 30. So, 2032.4 divided by 30 was 67.7 The computed as follows :

$$
\begin{aligned}
& M x=\frac{\sum x}{N} \\
& M x=\frac{2032.4}{30} \\
& =67.7
\end{aligned}
$$


BORJU: Borneo Educational Journal

https://jurnal.fkip-uwgm.ac.id/index.php/Borju/index

E-ISSN: 2655-9323

Februari 2019, Vol. 1 No. 1

\section{The Result of Post Test}

The following table, shows the scores of vocabulary test after teaching using video to the elementary second level students of SDN 018 Samarinda.

Table 6. The Scores of Post Test

\begin{tabular}{c|c|c}
\hline Number of Students & Score & Qualification \\
\hline 1 & 100 & $\mathrm{~A}$ \\
2 & 98.1 & $\mathrm{~A}$ \\
3 & 96.2 & $\mathrm{~A}$ \\
4 & 92.4 & $\mathrm{~A}$ \\
5 & 90.5 & $\mathrm{~A}$ \\
6 & 90.5 & $\mathrm{~A}$ \\
7 & 86.7 & $\mathrm{~A}$ \\
8 & 86.7 & $\mathrm{~A}$ \\
\hline
\end{tabular}

Table 6. The Scores of Post Test

\begin{tabular}{c|c|c}
\hline Number of Students & Score & Qualification \\
\hline 9 & 94.3 & A \\
10 & 98.1 & A \\
11 & 79.2 & B \\
12 & 86.7 & A \\
13 & 83 & A \\
14 & 77.3 & B \\
15 & 77.3 & B \\
16 & 73.5 & B \\
17 & 77.3 & B \\
18 & 64.1 & C \\
19 & 67.9 & C \\
20 & 66 & C \\
21 & 67.9 & C \\
22 & 60.3 & C \\
23 & 83 & A \\
24 & 73.5 & B \\
25 & 67.9 & C \\
26 & 60.3 & C \\
27 & 71.6 & B \\
28 & 71.6 & B \\
29 & 50.9 & D \\
30 & 69.8 & C \\
\hline SUM & 2362.6 & \\
\hline
\end{tabular}

From the table above, we can see that sum of the score of Post Test was 2362.6 and the number of the students was 30 . So, 2362.6 divided by 30 was 78.7

The computed as follows :

$$
\begin{aligned}
M x & =\frac{\sum x}{N} \\
M x & =\frac{2362.6}{30} \\
& =78.7
\end{aligned}
$$


Based on the result of the post test, the writer concluded that the students who were taught by using video was more successful than before treatment. It is proved in the result of the post test score after treatment which was higher than that before treatment, that is the mean score of pre test was 67.7. While the mean score of post test was 78.7. To see weather the difference between the mean score was significant or not, the writer used t-test to measure the difference.

\section{Data Analysis}

After the writer collected the data of the test from the students, she analyzed the data by using ttest. This analysis was used to look for significant difference between the students in vocabulary before and after the treatment. The following table showed the computation of the data.

Table 7. The scores of the students test before and after the treatment

\begin{tabular}{c|c|c|c|c}
\hline $\begin{array}{c}\text { Number of } \\
\text { students }\end{array}$ & $\begin{array}{c}\text { Before } \\
\text { Treatment } \\
\text { Score (a) }\end{array}$ & $\begin{array}{c}\text { After Treatment } \\
\text { Score (b) }\end{array}$ & $\begin{array}{c}\text { Difference } \\
\text { (D) }\end{array}$ & $\begin{array}{c}\text { Square } \\
\text { Difference } \\
\left(\mathrm{D}^{2}\right)\end{array}$ \\
\hline 1 & 96.2 & 100 & 3.8 & 14.4 \\
2 & 94.3 & 98.1 & 3.8 & 14.4 \\
3 & 94.3 & 96.2 & 1.9 & 3.6 \\
4 & 86.7 & 92.4 & 5.7 & 32.5 \\
5 & 86.7 & 90.5 & 3.8 & 14.4 \\
6 & 84.9 & 90.5 & 5.6 & 31.3 \\
7 & 83 & 86.7 & 3.7 & 13.7 \\
8 & 79.2 & 86.7 & 7.5 & 56.2 \\
9 & 77.3 & 94.3 & 17 & 289 \\
10 & 75.4 & 98.1 & 22.7 & 515.3 \\
\hline
\end{tabular}


BORJU: Borneo Educational Journal

https://jurnal.fkip-uwgm.ac.id/index.php/Borju/index

E-ISSN: 2655-9323

Februari 2019, Vol. 1 No. 1

Table 7. The scores of the students test before and after the treatment

\begin{tabular}{c|c|c|c|c}
\hline $\begin{array}{c}\text { Number of } \\
\text { students }\end{array}$ & $\begin{array}{c}\text { Before } \\
\text { Treatment } \\
\text { Score (a) }\end{array}$ & $\begin{array}{c}\text { After Treatment } \\
\text { Score (b) }\end{array}$ & $\begin{array}{c}\text { Difference } \\
(\mathrm{D})\end{array}$ & $\begin{array}{c}\text { Square } \\
\text { Difference } \\
\left(\mathrm{D}^{2}\right)\end{array}$ \\
\hline 11 & 73.5 & 79.2 & 5.7 & 32.5 \\
12 & 71.6 & 86.7 & 15.1 & 228 \\
13 & 71.6 & 83 & 11.4 & 129.9 \\
14 & 69.8 & 77.3 & 7.5 & 56.2 \\
15 & 69.8 & 77.3 & 7.5 & 56.2 \\
16 & 66 & 73.5 & 7.5 & 56.2 \\
17 & 66 & 77.3 & 11.3 & 127.7 \\
18 & 62.2 & 64.1 & 1.9 & 3.6 \\
19 & 60.3 & 67.9 & 7.6 & 57.7 \\
20 & 60.3 & 66 & 5.7 & 32.5 \\
21 & 58.4 & 67.9 & 9.5 & 90.2 \\
22 & 58.4 & 60.3 & 1.9 & 3.6 \\
23 & 56.6 & 83 & 26.4 & 696.9 \\
24 & 56.6 & 73.5 & 16.9 & 285.6 \\
25 & 54.7 & 67.9 & 13.2 & 174.2 \\
26 & 52.8 & 60.3 & 7.5 & 56.2 \\
27 & 49 & 71.6 & 22.6 & 510.7 \\
28 & 45.2 & 50.9 & 5.7 & 32.5 \\
29 & 47.1 & 71.6 & 24.5 & 600.2 \\
30 & 24.5 & 69.8 & 45.3 & 2052 \\
\hline Total & 2032.4 & 2362.6 & 330.2 & 6267.4 \\
& & & & \\
\hline
\end{tabular}

Then the difference was computed as follows :

$$
\begin{array}{cccc}
M x=\frac{\sum x}{N} & M x=\frac{\sum x}{N} \quad M x=\frac{2362.6}{30} & D=\frac{\sum 30.2}{30} & \\
M x=\frac{2032.4}{30} & =78.7 & & \\
=67.7 & M 11
\end{array}
$$

Based on the table, it is found :

$\sum \mathrm{x}=$ Sum of the total score of the test before treatment was 2032.4

$\sum \mathrm{y}=$ Sum of the total score of the test after treatment was 2362.6

$\mathrm{D} \quad=$ Differences was 11

$\sum \mathrm{D}=$ Sum of difference between $\mathrm{x}$ and $\mathrm{y}$ was 330.2

$\sum \mathrm{D} 2=$ Square difference was 6267.4

$\mathrm{N} \quad=$ Number of students was 30

Then using the t-test formula the data was computed :

$$
t=\frac{D}{\sqrt{\frac{\sum D^{2}-\frac{\left(\sum D\right)^{2}}{N}}{N(N-1)}}}
$$




$$
\begin{gathered}
t=\frac{11}{\frac{\sqrt{6267.4-\frac{(330.2)^{2}}{30}}}{30 \times(30-1)}} \\
t=\frac{11}{\sqrt{\frac{6267.4-3634.40}{870}}} \\
t=\frac{11}{\sqrt{\frac{2633}{870}}} \\
t=\frac{11}{\sqrt{3.02}} \\
t=\frac{11}{1.73} \\
t=6.358
\end{gathered}
$$

After finding out the result of the computed t-test, the writer found degree of freedom for t-test. The writer used the formula n-1 for degree of freedom. Number of students was 30 . So, the writer got $\mathrm{df}=29$. Then the writer go to $\mathrm{t}$-table to see the value of $\mathrm{df}=29$ at level of significance 5\%, the value for $\mathrm{df}=29$ was 2.045 . the data analysis indicates that the computed $\mathrm{t}$ was higher than $\mathrm{t}$ table $(6.358>2.045)$.

So, the null hypothesis (Ho) was rejected and the alternative hypothesis (Ha) was accepted. It can be conclude there was significant effect of the use of video on English vocabulary mastery of the elementary second level students at SDN 018 Samarinda. It means that video has good effect in teaching English vocabulary to the elementary second level students of SDN 018 Samarinda.

\section{Discussion}

Based on the findings of the study the writer could make some interpretation. The writer interpreted the data from the previous chapter in order to give clear explanation the difference of English vocabulary mastery of the elementary second level students of SDN 018 Samarinda before and after using video.

Based on Table 5 the score of pretest and table 6 the scores of posttest, it shows that the result of mean score in pretest without using video was 67.7, it's mean that the result of the student vocabulary mastery without using video was fair. It can be said that some of the students answer the vocabulary test with false. And that the result of mean score in posttest with using video was 78.7 , this shows that the result of the student vocabulary mastery with using video was good. It can be said that most of the students answer the vocabulary test with true.

So, this study has proved that using video was better than without using video especially in vocabulary mastery to increase the ability of the students. It supported from the chapter II. Miarso (1984, cited in Saidah, 2004), said that video was used as a teaching technique to increase the student's motivation to the material subject. We could say that teaching vocabulary using video had advantages and gave better result.

The value of t-test result the writer found out 6.358 as the value of the t-test calculation. It gives a fact that $\mathrm{t}$ - value is greater than the value of $\mathrm{t}$ - table (2.045) at the 5\% of level significance of 
$(6.358>2.045)$. Since this $\mathrm{t}-$ computed is greater than $\mathrm{t}$ - table. It means that null hypothesis (Ho) is rejected and the alternative hyphothesis (Ha) is accepted. So, there is any significant effect of the use of video on English vocabulary mastery to the elementary second level students at SDN 018 Samarinda.

There were some weaknesses found in this research. First, the instrument test was not sufficient to represent all the topic because there are some items dropped in try out. There are five topic in this research, they are body and face, occupations, animals, clothes, and things in the classroom. The detailed of distribution of items were body and face (14 items), occupations (12 items), animals ( 8 items), clothes (11 items), and things in the classroom (8 items). And the second, less frequency of meeting.

Based on the writer's experience when conducted the study, the students were interested and have been motivated in learning vocabulary using video. The students also enjoyed following the lesson, it gave effect to the result on vocabulary mastery. The results of the study support the video theory. The scores of the students increase after the writer gave treatment using video. It supported from the chapter II . According to Wardani (2003), she investigated about teaching vocabulary through movies towards. The result showed that practicing vocabulary by movies towards was more effective than practicing vocabulary without movies towards, and also resulted better achievement, in addition, Saidah (2004) she investigated about teaching vocabulary by using language laboratory (control group) and using video (experimental group). The result that the teaching vocabulary by using video was successful than teaching vocabulary by using language laboratory.

This study showed that teaching vocabulary by using video increased the vocabulary mastery. Video for the students that contains vocabulary was one of interesting technique in English teaching process. Vocabulary was very important, particularly, sufficient English vocabulary could give a practical help in developing the four interrelated skills in language learning, namely listening, speaking, reading and writing.

\section{CONCLUSIONS}

Based on the findings study about the effect of teaching English vocabulary by using video to the elementary second level students of SDN 018 Samarinda, the writer found the conclusion as follows :

1. The mean scores of the students' vocabulary result before using video of the elementary second level students of SDN 018 Samarinda was 67.7 (fair)

2. The mean scores of the students' vocabulary result after using video of the elementary second level students of SDN 018 Samarinda was 78.7 (good)

3. There was a significant difference in the students' vocabulary results before and after using video. From the computation done in this study, the value of $t_{c}(6.358)$ was much higher than value of $\mathrm{t}_{\mathrm{t}}(2.045)$ at the 0.05 level. It indicates that the Null Hypothesis (Ho) was rejected and Alternative Hypothesis (Ha) was accepted. It also be stated that teaching vocabulary by using video gives better result in vocabulary mastery than before using video. 
BORJU: Borneo Educational Journal

https://jurnal.fkip-uwgm.ac.id/index.php/Borju/index

E-ISSN: 2655-9323

Februari 2019, Vol. 1 No. 1

\section{REFERENCES}

[1] Arikunto, Suharsimi. Dasar - Dasar Evaluasi Pendidikan. Jakarta: PT. Bina Aksara. 2008.

[2] Barnhart, L, Clarence, Barnhart, K, Robert. 1988. World Book Dictionary. Philippines: Scot, Foresman and Company.

[3] Budiharso, Teguh. 2001. Pengantar Penelitian. Samarinda: Makalah.

[4] Creswell, W. John. 1987. Research Design Qualitative, Quantitative, and Mixed Methods (2 ${ }^{\text {th }}$ Edition).

[5] Guralnik, B, David. 1983. Webster's Encyclopedic Unabridged Dictionary of theEnglish Language. New Work : Dilithium Press, Ltd.

[6] Hasanah, Sholiehatun. 2011. The Effect of Using Word Mapping on Vocabulary Achievement of the Second Year Students of SMPN 001 Long Ikis in theAcademic Year 2010/2011. Unpublished Thesis. Samarinda: Mulawarman University.

[7] Hornby, A.S. 2000. OxfordLearner's Dictionary of Current English. New York : Oxford University Press.

[8] Longman. 1998. Dictionary of Contemporary English. England: Longman Group UK. Limited.

[9] Madil, Suhaemi. 2011. The Effect of Using Pictures in Teaching English Vocabulary to the Fifth Grade Students of SD 004 Bengalon AcademicYear 2009/2010. Unpublished Thesis. Samarinda: Mulawarman University

[10] Mansion, E.J. 1963. Heath's Standard French and English Dictionary. French: D.C. Heath and Company.

[11] Ranggi, Yunita. 2010. The Effect of Teaching English Vocabulary by Using Puzzle Games to the Fourth Grade Students of SDN 006 Samarinda in theAcademic Year 2009/2010. Unpublished Thesis. Samarinda: Mulawarman University.

[12] Saidah. 2004. The Use of Video and Language Laboratory in Teaching Vocabulary for the Second Year Students of SLTPN 3 Tenggarong. Unpublished Thesis. Samarinda: Mulawarman University.

[13] Wardani, Purnama. 2003. The Effect of VCD Towards Students Vocabulary Achievement of the Fifth Grade at SDN 003 Palaran in Academic Year2001/2002. Unpublished Thesis. Samarinda: Mulawarman University.

[14] Wilda, Sofia. 2009. The Effect of Audio Visual Aids on Vocabulary Achievement of the Fourth Grade Students of SDN 023 Samarinda Ulu in Academic Year 2008/2009. Unpublished Thesis. Samarinda: Mulawarman University 